\title{
The Selection of the Language in Indonesian Learning at SMK Multi Karya Medan
}

\author{
Ruth Remilani Simatupang*), \\ Universitas Sebelas Maret \\ Muhammad Rohmadi, \\ Universitas Sebelas Maret \\ Kundharu Saddhono, \\ Universitas Sebelas Maret \\ *) Correspondences author: J1. Ir sutami 36 A Surakarta, 57126, Surakarta; Indonesia \\ e-mail: ruthremilani@gmail.com
}

\begin{abstract}
This study aims to describe the function the code switching used by speakers at SMK Multi Karya Medan. This research is a descriptive qualitative research. The subjects in this study were the teacher and the students. The objects were the utterances of code-switching in Indonesian language learning in SMK Multi Karya Medan. Validity data technique is used triangulation of data source and informant review. Data collection is using listen and speak methods. Data analysis using the intralingual method. The result of the research showed that the function of code-switching at the time of the process of Indonesian language learning are emphasized, reprimanded, reminded, explained, asked and commanded.
\end{abstract}

Key Words: code switching, function, Batak Toba.

Article History: Received: 20/06/2018; Revised: 25/07/2018; Accepted: 13/08/2018; Published: 22/08/2018

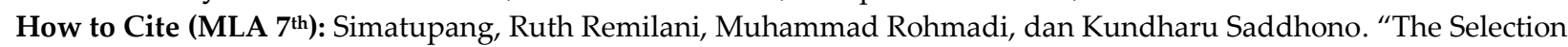
of the Language in Indonesian Learning at SMK Multi Karya Medan" Hortatori Jurnal Pendidikan Bahasa dan Sastra Indonesia 2.1 (2018): 51-56. Print/Online. Copyrights Holder: Simatupang, Ruth Remilani, Muhammad Rohmadi, dan Kundharu Saddhono. First Publication: Hortatori Jurnal Pendidikan Bahasa dan Sastra Indonesia (2018).

This work is licensed under a Creative Commons Attribution-ShareAlike 4.0 International License.

\section{Pendahuluan}

Bahasa sebagai alat komunikasi yang dilakukan dalam hal berinteraksi dalam kehidupan manusia khususnya dalam lingkungan pendidikan. Guru dan siswa dalam proses pembelajaran sangat berkaitan dengan bahasa. Guru dalam menyampaikan pembelajaran pada siswa tentu dengan menggunakan bahasa. Bahasa yang disampaikan guru tersebut akan ditangkap oleh siswa, Sehingga siswa dapat merespon dan menanggapi penjelasan maksud guru tersebut. Pembelajaran bahasa berfungsi sebagai sarana untuk meningkatkan kemampuan berpikir manyampaikan ide- ide maupun gagasan dengan tujuan untuk memperluas wawasan. Bahasa mempunyai fungsi sosial, baik sebagai alat komunikasi untuk berinteraksi maupun sebagai cara mengidentifikasikan kelompok sosial. P.W.J. Nababan (1986:49) menyatakan bahwa fungsi bahasa yang paling utama adalah sebagai alat untuk komunikasi antara sesama manusia, sebab tanpa komunikasi kebahasaan, sistem social kemasyarakatan tidak akan terwujud. Tanpa bahasa manusia tidak dapat berinteraksi dengan yang lain serta tidak dapat menjalin hubungan kekerabatan antara yang satu dengan yang lain. Sehingga bahasa memiliki fungsi utama untuk berkomunikasi.

Pembelajaran bahasa Indonesia saat ini sangat banyak ditemukan tentang penggunaan alih kode khususnya dalam interaksi di kelas. Pengkajian tentang alih kode merupakan pembelajaran sosiolinguistik. Sosiolinguistik adalah suatu pengkajian tentang bahasa yang dikaitkan dengan kondisi masyarakat atau kelompok.masyarakat dalam hal berinteraksi menggunakan bahasa sebagai alat untuk berinteraksi dengan fungsi untuk menjalin kekrabatan antara satu dengan yang lain sehingga digunakan bahasa yang mampu 
dipahami satu sama yang lain. Di lingkungan pendidikan tentu menggunakan bahasa sebgai alat komunikasi. Bahasa yang digunakan ialah bahasa - bahasa yang dapat dimengerti oleh kedua belah pihak sehingga terjalin kekerabatan yang baik. Banyak sekali di temukan bahasa - bahasa yang digunakan untuk berinteraksi khusunya bahasa - bahasa yang ada di Indonesia.

Indonesia terdiri dari beberapa bahasa daerah bahkan setiap suku memiliki bahasa tersendiri sehingga dalam hal pemakaian bahasa terjadi peralihan dari bahasa yang satu ke bahasa yang lain. Banyak sekali daerah diIndonesia yang menggunakan bahasa daerah yaitu bahasa Batak Toba, bahasa jawa, bahasa sunda dan lain - lain. Bahasa daerah ialah bahasa yang merupakan bahasa yang lahir dari social budaya masyarakat. Lingkungkungan pendidikan juga banyak sekali ditemukan peralihan bahasa yang satu ke bahasa yang lain. Peralihan bahasa yang satu ke bahasa yang lain di sebut alih kode. Alih kode merupakan gejala peralihan pemakaian bahasa karena berubah situasi (Appel, dkk1976:103). Selain itu Subroto juga berpendapat alih kode merupakan bentuk tuturan yang beralih atau berpindah dari suatu bahasa ke bahasa yang lain, dari satu variasi yang lain, atau dari satu dialek ke dialek lain. Alih kode terjadi karena alasan dan motivasi tertentu yang dilakukan secara sadar atau sengaja (Subroto, 2002). Alih kode merupakan bergantinya penggunaan suatu kode ke kode yang lain (Chaer, 2012).

Banyak ditemukan penggunaan alih kode dalam proses pembelajaran. Penelitian dilakukan oleh Sundoro (2018) terkait Pemakaian Bahasa Jawa Banyumasan dalam Pembelajaran Bahasa Indonesia SMK (Kajian Sosiolinguistik). Dalam penelitiannya ditemukan dalam pembelajaran bahasa Indonesia di kelas X dan XI SMK Negeri 1 Banyumas terdapat jenis alih kode intern dan ekstern. Alih kode internal dalam proses pembelajaran Bahasa Indonesia di kelas X dan XI SMK Negeri 1 Banyumas yaitu alih kode dari bahasa Indonesia ke bahasa Jawa Banyumasan dan alih kode dari bahasa Jawa Banyumasan ke bahasa Indonesia.

Penelitian lainnya dilakukan oleh Husnan (2018) tentang kategori fungsi alih kode siswa bajo dalam kelas pembelajaran bahasa inggris sebagai bahasa asing. Hasil penelitiannya ditemukan fungsi alih kode sebagian besar dalam bentuk komentar siswa (pupils comment) sebanyak 44\% dengan 129 bukti, tergolong kurang dominan. Kategori penjelasan tata bahasa (grammar explanation) sebanyak 20\% dengan 58 bukti, tergolong tidak dominan. Kategori lainnya tergolong tidak dominan. Sebagian besar kategori fungsi alih kode menggunakan bahasa Indonesia sebesar 50,68\% dengan 148 bukti, tergolong dominan, sedangkan bahasa Inggris sebesar 34,59\% dengan 101 bukti, tergolong kurang dominan. Dua bahasa yang lain, Bajo sebanyak 8, 22\% dan Sasak sebanyak 6, 51\%, termasuk tidak dominan. Sehingga dalam penelitian tersebut menggunakan empat bahasa yakni bahasa Inggris bahasa Indonesia, bahasa Bajo dan bahasa Sasak.

Penelitian relevan dilakukan oleh Marwan (2016) terkait alih kode dan campur kode dalam pemerolehan bahasa anak dalam penelitiannya menunjukkan bahwa struktur kalimat anak dalam pemerolehan bahasa merupakan jenis kalimat sederhana sehingga dalam hal ini pengaruh yang melatar belakangi pemerolehan bahasa anak ialah bahasa ibu.yatu bahasa pertama yang dikenal dan menajdi bahasa sehari - hari yang didengarkan oleh si anak.

Bilingualism atau sering dikatakan dengan kedwibahasaan merupakan indivisu yang paham dua bahasa dalam suatu situasi. Bilingualism merupakan salah satu faktor terjadinya alih kode khusunya dalam proses pemeblajaran. Guru dalam hal menjelaskan kerap sekali dijumpai menggunakan alih kode pada awalnya guru menggunakan bahasa indoneisa namun dalam hal menjelaskan guru terkadang menggunakan alih kode ke bahasa daerah. Bahasa daerah yang digunakan sesuai dengan bahasa yang sudah dipahami oleh penutur dan mitra tutur. Banyak sekali penelitian yang menunjukkan tentang bilingualime seperti (Kuhl, 2016), (Jasinska, 2017) dan (Fish 2017). Hasil penelitian menunjukkan bahwa bilingualisme dapat berdampak positif dalam hal belajar. Khususnya dalam hal menjelaskan guru dalpat menjelaskan materi pengajaran kepada siswa dengan menggunakan alih kode. Hal tersebut dilakukan untuk menciptakan suasana santai dan terjalin keakraban dalam berinteraksi.

SMK Swasta Multi Karya Medan merupakan Sekolah yang berada di Kota Medan. Namun mayoritas siswa tersebut merupakan suku Batak Toba dan sebagian besar mengerti bahasa Batak Toba karena siswa masih banyak berasal dari daerah dan mengerti serta paham tuturan bahasa Batak Toba. Dalam kesehariannya siswa juga menggunakn bahasa Batak Toba. Dalam berinteraksi baik di luar sekolah maupun di lingkungan sekolah menggunakan bahasa Batak Toba sehingga hal tersebut menjadi kebiasaan dan terbawa sampai dalam pembelajaran di kelas. Sehingga hal tersebut sangat mempengaruhi dalam 
penggunaan alih kode dalam pembelajaran di kelas. Dalam berinteraksi guru dan siswa menggunakan alih kode tentu memiliki fungsi dalam hal untuk mencapai tujuan pembelajaran.

Berdasarkan pemaparan diatas peneliti sangat tertarik dalam meneliti pemakaian bahasa khususnya dalam menganalisis fungsi alih kode yang digunakan tuturan dalam pembelajaran bahasa Indonesia dalam kelas di SMK Swasta Multi Karya Medan.

\section{Metode}

Penelitian tentang kajian sosiolinguistik ini dilaksanakan di SMK Swasta Multi Karya Medan Kecamatan Medan Amplas, Kota Medan Provinsi Sumatera Utara. Penelitian dilaksanakan dua bulan yakni bulan Oktober dan November. Subjek dalam penelitian ini adalah guru dan siswa. Objek dalam penelitian ini adalah tuturan penggunaan alih kode yang digunakan pada saat proses pembelajaran bahasa Indonesia. Penelitian ini menggunakan pendekatan deskriptif kualitatif. Setelah data didapatkan, lalu peneliti menuangkan hasil data yang didapatkan berupa fakta - fakta yang terjadi .pada saat proses pembelajaran tersebut. Metode pengumpulan data yang digunakan pada penelitian ini berupa metode simak dan cakap yakni memperoleh data dengan menyimak tuturan para penutur yakni guru dan siswa. Dalam penelitian ini menggunakan teknik simak bebas libat cakap yang disertai dengan penerapan teknik rekam dan catat. Pengamatan difokuskan pada fungsi alih kode dalam pembelajaran bahasa Indonesia. Observasi dilakukan berdasar pada pedoman observasi yang telah dibuat sebelumnya. Selama proses pembelajaran, peneliti tidak terlibat dalam percakapan.

Data yang terkumpul selanjutnya dianalisis dengan menggunakan metode padan intralingual. Metode padan intralingual merupakan metode analisis dengan cara menghubung banding unsur - unsur yang bersifat lingual baik yang terdaoat dalam satu bahasa maupun beberapa bahasa yang berbeda (Mahsun 2012:259-260). Selanjutnya Mahsun mengemukakan dalam anlisis kualitatif terdiri dari empat komponen yaitu (1) tahap penyediaan data; (2)reduksi data; (3) penyajian data; dan (4) pengambilan kesimpulan (Mahsun 2012:270). Hasil simpulan diperoleh berdasarkan fakta - fakta yang ditemukan selama proses penelitian berlangsung dalam tahap penuisan atau penyususnan laporan, sehingga diperoleh sebuah simpulan yang dikehendaki dari hasil penelitian ini.

\section{Hasil dan Diskusi}

Berdasarkan hasil penelitian yang ditemukan dalam proses pembelajaran bahasa Indonesia di SMK Swasta Multi Karya Medan terdapat penggunaan alih Kode. Alih kode yang digunakan tersebut tentu memiliki fungsi untuk mencapai tujuan pembelajaran. Fungsi alih kode tersebut ialah (1) menegaskan, (2) menegur, (3) meningatkan, (4) menjelaskan, (5) menanyakan dan (6) menyuruh. Berikut dapat diuraikan fungsi - fungsi alih kode yang ditemukan di SMK Swasta Marisi Medan pada saat proses pembelajaran Bahasa Indonesia.

\section{Menegaskan}

Menegaskan merupakan salah satu fungsi alih kode yang ditemukan peneliti di SMK Swasta Multi Karya Medan pada saat proses pembelajaran bahasa Indonesia. Dari hasil penelitian ditemukan beberapa tuturan yang menggunakan fungsi alih kode untuk menegaskan. Adapun tuturan tersebut diantaranya sebagai berikut.

\section{Data 1}

Guru : Kemaren kita sudah mempelajari tentang bagian - bagian surat. Sebutkan bagian - bagian surat resmi!

Siswa : Kepala surat, kop surat

Guru : Hanya itu

Siswa : Iya bu

Guru :Bege tu jolo sude asa diboto surat di buku tulis. Asa diingot(semua dengar ke depan supaya kalian mengerti kemudian tulis di buku catatan supaya kalian ingat)

Data diatas merupakan peristiwa alih kode dalam hal menegaskan. Guru menggunakan alih kode bahasa daerah yaitu bahasa Batak Toba. Pada awal percakapan guru menggunakan bahasa Indonesia dan siswa merespon dengan menggunakan bahasa Indonesia namun pada akhir kalimat guru menggunakan alih 
kode dengan tuturan "bege tu jolo sude asa diboto surat di buku tulis. Asa diingot! Artinya semua dengar ke depan supaya kalian mengrti kemudian tulis di buku catatan supaya kalian ingat. Guru menegaskan kepada siswanya dengan menggunakan alih kode supaya siswanya mendengar apa yang dijelaskan oleh guru tersebut di depan. Dan guru juga menegaskan supaya siswanya kemudia menuliskan apa yang dijelakan oleh guru tersebut. Guru menggunakan alih kode bahasa Batak Toba karena guru tersebut berasal dari bahasa Batak Toba dan mayoritas peserta didik juga merupakan suku Batak Toba yang mengerti bhasa Batak Toba sehingga guru dan peserta didik tersebut merupakan bilingalisme yaitu mengerti bahasa daerah yakni bahasa Batak Toba dan bahasa Indonesia. Sehingga dalam hal menegaskan guru menggunakan alih kdoe dari bahasa Indonesia ke bahasa Batak Toba.

\section{Menegur}

Fungsi alih kode yang kedua ialah fungsi dalam hal menegur. Fungsi dalam hal menegur ditemukan peneliti di SMK Swasta Multi Karya Medan pada saat proses pembelajaran bahasa Indonesia di kelas. Dari hasil penelitian ditemukan beberapa tuturan yang menggunakan fungsi alih kode untuk menegur. Adapun tuturan tersebut diantaranya sebagai berikut.

Data 2

Guru : Segera dikerjakan tugas yang ada di buku paketnya, Nanti istirahat pertama dikumpulkan

Siswa: Besok la bu

Guru : Bah gabe hamu mangatur. pokokna istirahat dikumpul (kok jadi kalian yang ngatur. Pokoknya nanti jam istirahat tugas dikumpu)

Siswa : Olo bu (iya bu).

Data diatas merupkan peristiwa alih kode dari bahasa Indonesia ke bahasa Batak Toba. Pada awal percakapan guru menggunakan bahasa Indonesia dengan tuturan "segera dikerjakan tugas yang ada di buku paketnya, Nanti istirahat pertama dikumpulkan" dalam tuturan tersebut guru menyuruh siswa untuk mengerjakan tugas yang ada di buku paketnya dan siswa merespon dengan menggunakan bahasa Indonesia. Namun karena guru melihat situasi dimana siswa tidak mematuhi perintahnya sehingga guru tersebut menggunakan alih kode dengan meneguru siswa tersebut "bah gabe hamu mangatur. pokokna istirahat dikumpul. Artinya kok jadi kalian yang ngatur. Pokoknya nanti jam istirahat tugas dikumpul guru tersebut menggunakan alih kode yang berfungsi menegur siswanya karena siswa kurang mematuhi perintahnya dalam hal mengumpulkan tugas. Alih kode diguankan guru karena guru mengetahui kondisi di kelas tersebut karena guru mengetahui bahwa siswanya merupakan kebanyakan suku Batak Toba dan mengerti bahasa Batak Toba sehingga dalam hal menegur guru menggunakan bahasa Batak Toba. Dan siswa tersebut meresponnya dengan menggunakan alih kode juga yaitu bahasa daerah datak toba. Supaya kondisi tersebut tidak menjadi tegang dan merespon teguran guru dengan menggunakan bahasa Batak Toba.

\section{Mengingatkan}

Fungsi alih kode yang kedua ialah fungsi dalam hal meningatkan. Fungsi dalam hal meingatkan ditemukan peneliti di SMK Swasta Multi Karya Medan pada saat proses pembelajaran bahasa Indonesia di kelas. Dari hasil penelitian ditemukan beberapa tuturan yang menggunakan fungsi alih kode untuk meningatkan. Adapun tuturan tersebut diantaranya sebagai berikut.

\section{Data 3}

Guru : Apakah semua sudah mengerjakan tugas yang saya suruh minggu yang lalu tentang menulis salah satu surat resmi.

Siswa : Lupa bu

Guru : Siapa yang sudah selesai

Siswa : Yang essay bu

Guru : Olo dikarejoi di jabu unang adong na lupa ditanda tangani orang tua dah.( iya nanti kembali

dikerjakan di rumah jangan ada sempat yang melupakan tugas lagi, lalu semua nya ditanda tangani orang tua di rumah.)

Data diatas merupakan peristiwa alih kode dari bahasa Indonesia ke bahasa batk toba yaitu pada awal percakapan guru menggunakan bahasa Indonesia dalam hal mengingatkan peserta didiknya dengan 
tuturan "apakah semua sudah mengerjakan tugas yang saya suruh minggu yang lalu tentang menulis salah satu surat resmi dan siswa merespon tuturan guru tersebut dengan menggunakan bahasa Indonesia dengan respon "lupa bu" mendengar hal tersebut guru menggunakan alih kode di akhir percakapan yaitu dari bahasa Indonesia ke bahasa Batak Toba dengan tuturan "olo dikarejoi di jabu unang adong na lupa ditanda tangani orang tua dah". Artinya iya nanti kembali dikerjakan di rumah jangan ada sempat yang melupakan tugas lagi, lalu semua nya ditanda tangani orang tua di rumah. Alih kdoe diguankan guru terhadap peserta didik dalam hal mengingatkan tugas yang sudah diberikan oleh guru tersebut minggu yang lalu sehingga guru tersebut menggunakan alih kode dengan mengingatkan kembali siswanya supaya mengerjakan tuga stersebut di rumah dan ditanda tangani orang tua supaya siswa tersebut tidak lupa. Alih kode tersebut dilakukan oleh guru karena guru dan siswa merupakan bilingualisme yaitu mengertia dua bahasa yakni bahasa daerah yaitu bahasa Batak Toba dan bahasa Indonesia. Sehingga guru tersebut menggunakan alih kode dalam hal mengingatkan kembali siswanya. Hal tersebut terjadi supaya menjalin keakraban dengan siswanya.

\section{Menjelaskan}

Menjelaskan merupakan salah satu fungsi alih kode yang ditemukan peneliti di SMK Swasta Multi Karya Medan pada saat proses pembelajaran bahasa Indonesia. Dari hasil penelitian ditemukan beberapa tuturan yang menggunakan fungsi alih kode untuk menjelaskan. Adapun tuturan tersebut diantaranya sebagai berikut.

Data 4

Guru : Molo surat pribadi dang adong perihal dohot nomor surat (kalau surat pribadi tidak ada menggunakn perihal maupun nomor surat.)

Siswa : Jadi langsung tu isi na bu?(jadi langsung tu isi na bu)

Guru : Iya bisa tapi lebih baiknya kamu mengucap salam dalam surat dan tanggal pembuatannya.

Data tersebut merupakan peristiwa alih kode. Guru pada awal percakapan menggunakan bahasa batak dalam hal menjelaskan tentang surat alasa guru menggunakan bahasa Batak Toba dalam pemebalajaran bahasa Indonesia supaya menciptakan suasana santai dan tidak menegangkan supaya siswa dalam kelas tidak merasa jenuh dan bosan ketika proses pembelajaran berlangsung. Dalam hal ini guru menjelaskan dengan bahasa Batak Toba dengan tuturan "molo surat pribadi danag adong perihal dohot nomor surat ártinya kalau surat pribadi tidak ada menggunakn perihal maupun nomor surat. Sehingga tuturan tersebut langsung direspon oleh siswanya dengan menggunakan tuturan bahasa Batak Toba yaitu "jadi langsung tu isi na bu?'artinya langsung keisinya bu. Hal tersebut siswa juga kembali menggunakan tuturan bahasa toba karena awalnya guru juga menggunakan tuturan bahasa Batak Toba namun pada akhir percakapan guru menggunakan alih kode ke bahasa Indonesia karena memahami kondisi walaupun sebagian besar siswanya merupakan suku Batak Toba untuk menghormati yang memiliki suku selain bahasa Batak Toba guru menggunakan bahasa Indonesia dengan tuturan " Iya bisa tapi lebih baiknya kamu mengucap salam dalam surat dan tanggal pembuatannya." Alih kode digunakan guru tersebut dalam hal menjelaskan guru beralih kode dari bahas aBatak Toba ke bahasa Indonesia.

\section{Menanyakan}

Menanyakan merupakan salah satu fungsi alih kode yang ditemukan peneliti di SMK Swasta Multi Karya Medan pada saat proses pembelajaran bahasa Indonesia. Dari hasil penelitian ditemukan beberapa tuturan yang menggunakan fungsi alih kode untuk menanyakan. Adapun tuturan tersebut diantaranya sebagai berikut.

Data 5

Guru : Adong na mambuan KBBI?( adakah yang membawa KBBI)

Siswa : Adong si heri bu (ada bu si heri)

Guru : Pinjam dulu heri sebentar

Data diatas merupakan peristiwa alih kode. Alih kode digunakan guru dalam hal menanyakan siswa dengean pertanyaan "adong na mambuan KBBI?" artinya adakah yang membawa KBBI (Kamus Besar Bahasa Indonesia)? Pada tuturan tersebut guru menggunakan bahasa Batak Toba karena guru memahami kondisi agar terlihat santai sehingga dalam hal bertanya guru tersbut menggunakan bahasa 
Batak Toba karena guru memahami bahwa sebagian besar siswa yang ada dalam kelas tersebut suku Batak Toba yang mengerti bahasa Batak Toba. Sehingga dalam hal bertanya pada saat proses pembelajaran bahasa Indonesia guru menggunakan bahasa Batak Toba. Muris merespon pertanyaan guru tersebut dengan menggunakan bahasa Indonesia dengan menjawab "adong si heri bu" mendengar hal tersebut guru beralih kode di akhirr percakapan dengan menggunakan bahasa Indonesia "pinjam dulu heri sebentar". Karena guru tersebut mengetahui bahwa si heri berasal dari suku Nias namun sudah terbiasa dengan mendengar bahasa Batak Toba. Sehingg aguru beralih kode dengan menggunakn bahasa Indonesia supaya heri mengerti maksdu tuturan guru tersebut sehingga guru beralih kode dalam hal menanyakan. Situasi tersbut menandakan bahwa siswa dan guru merupakan bilingaulisme atau paham dua bahasa.

\section{Data 6}

Guru : Ada yang tidak mengrti seputar tentang pelajaran yang saya jelaskan tadi?.

Siswa: Sudah bu

Guru : Jadi nga diboto be? Nga boi hita ulangan?( apakah sudah mengerti? Apakah kita sudah bisa ulangan?

Peristiwa diatas mmerupakan penggunaan alih kode yaitu guru menggunakan alih kode dalam hal menanyakan. Pada awal percakapan guru menggunakan bahasa Indonesia dengan menanyakan "Ada yang tidak mengrti seputar tentang pelajaran yang saya jelaskan tadi?. Guru mananyakan pada siswa apakah pelajaran yang guru sampaikan sudah dimengerti para siswa tersebut dan spontan siswa menjawab "sudah bu" siswa juga menggunakan bahasa indoneisa namun diakhir percakapan guru menggunakan alih kode menanyakn apa yang telah dijawa oleh siswa tersebut dan menanyakan pertanggung jawaban atas apa yang telah dijawab siswa tersebut dengan tuturan pertanyaan "Jadi nga diboto be? Nga boi hita ulangan?" artinya apakah sudah mengerti? Apakah kita sudah bisa ulangan? Gruu menggunakan alih kode dalam hal menayakan hal tersebut dilakukan supaya susana tidak tegang. Alih kode dilakukan karena guru dan siswa merupakan bilingaulisme yaitu mengerti bahasa daerah yaitu bahasa batk toba dan bahasa Indonesia.

\section{Menyuruh}

Fungsi alih kode yang kedua ialah fungsi dalam hal menyuruh. Fungsi dalam hal menyuruh ditemukan peneliti di SMK Swasta Multi Karya Medan pada saat proses pembelajaran bahasa Indonesia di kelas. Dari hasil penelitian ditemukan beberapa tuturan yang menggunakan fungsi alih kode untuk menyuruh. Adapun tuturan tersebut diantaranya sebagai berikut.

Data 3

Guru : Buka buku paketnya baca dan pahami terlehib dahulu.

Siswa : Iya bu

Guru : Gus hapus jo papan tulis on(gus hapus papan tulis ini dulu).

Data diatas merupakan penggunaan alih kode. Diawal percakapan guru menggnakan bahasa Indonesia dengan menyuruh siswa untuk membuka buku paketnya dengan tuturan "Buka buku paketnya baca dan pahami terlehib dahulu." Siswa mematuhi perintahn guru tersebut dan menjawab "iya bu" namun di pada pembelajaran guru beralih kode dari bahasa Indonesia ke bahasa Batak Toba dengan menyuruh agus untuk menghapus papan tulis dengan menggunakan bahasa Batak Toba" Gus hapus jo papan tulis on" artinya gus hapus papan tulis ini dulu. Guru menyuruh agus dengan menggunakan alih kode yaitu bahasa Batak Toba. Guru menggunakan alih kode dari bahasa Indonesia ke bahasa Batak Toba karean guru mengetahui bahwa agus merupakan suku Batak Toba dan mengerti bahasa Batak Toba sehingga munculnya penggunaan alih kode tersebut. alih kode dilakukan guru untuk menjalin keakraban dengan agus supaya suasan terlihat santai. Disini terlihat antara guru dan siswa merupakan bilingaulisme atau mengrti dua bahasa dalam suatu situasi sehingga dalam hal menyuruh guru mengguankan alih kode dari bahasa Indonesia ke abhasa Batak Toba. 


\section{Simpulan}

Bilingualisme atau kedwibahasaan merupakan salah satu faktor terjadinya alih kode. Hal tersebut terjadi dalam pembelajaran di kelas. Guru dan siswa dalam hal berinteraksi seing menggunakan alih kode, dalam hal ini alih kode yang digunakan tentu memiliki fungsi yang dapat memberikan tercapainya tujuan pembelajaran. Pembelajaran bahasa sangat berkaitan dengan penggunaan alih kode khususnya dalam hal menyampaikan pembelajaran. Alih kode tersebut digunakn karena meiliki fungsi dalam mecapai tujuan pembelajaran. Fungsi alih kode yang ditemukan ialah (1) menegaskan, (2) menegur, (3) mengingatkan, (4) menjelaskan, (5) menanyakan dan (6) Menyuruh.

\section{Ucapan Terima Kasih}

Penulis menyampaikan ucapan terima kasih yang tulus kepada Pembimbing yaitu kepada Dr Muhammad Rohmadi, M.Hum dan Dr. Kundahru Saddhono, S.S., M.Hum yang telah membimbing penulis dari awal penelitian hingga selesainya penelitian ini. Penulis juga mengucapkan kepada kepala sekolah SMK Multi Karya Medan serta guru terlebih guru bahasa Indonesia yaitu Lisa Septia Dewi Ginting, S.Pd., M.Pd dan tidak lupa juga mengucapkan terimakasih kepada siswa kelas X TSM SMK Swasta Multi Karya Medan yang telah mengijinkan dan memberikan waktu hingga peneliti menyelesaikan penelitian. Berterimakasih juga kepada orangtua yang memberikan motivasi serta dukungan doa dan materi hingga terwujudnya penelitian ini.

\section{Daftar Rujukan}

Appel.dkk. Sosiolinguitiek. Utrech - Antwerpen: Het Spectrum, 1976. Print.

Chaer, A. Linguistik Umum. Yogyakarta: Rineka Cipta, 2012. Print.

Fish, Melanie S, dkk. (2017). Infant-directed speech in English and Spanish:

Assessments of monolingual and bilingual caregiver VOT. Science Direct, 63, 19-34.

Husnan. Kategori Fungsi Alih Kode Siswa Bajo dalam Kelas Pembelajaran Bahasa Inggris Sebagai

Bahasa Asing. Jurnal Aksara 28, (2), (2016 ): 253-268.

Jasinska, (2017). Bilingualism yields language-specific plasticity in left

hemisphere's circuitry for learning to read in young children Science

Direct, 98, 34-45.

Kuhl, Patricia K, dkk. (2016). Neuroimaging of the bilingual brain: Structural

brain correlates of listening and speaking in a second language. Science

Direct, 162, 1-9.

Mahsun. (2012). Metode Penelitian Bahasa: Tahapan Srategi, Metode, dan Tekniknya. Jakarta: Rajawali Press.

Marwan. (2016). Alih Kode dan Campur Kode dalam Pemerolehan Bahasa Anak. jurnal wacana, $1,(1),(32-40)$

Nababan, P.W.J. (1986.) Sosiolinguistik. Jakarta: PT.Gramedia.

Subroto, E. D. dan M. D. dan S. (2002). Alih Kode dan Campur Kode Dalam Pernikahan Adat Surakarta. Jawa Tengah: Proyek Pembinaan Bahasa dan Sastra Indonesia dan Daerah Jawa tengah

Sundoro dan Suwandi, Sarwiji dan Setiawan Budhi. (2018). Pemakaian Bahasa Jawa Banyumasan dalam Pembelajaran Bahasa Indonesia SMK (Kajian Sosiolinguistik). Jurnal Gramatika 4, (1) (24-36) 